\title{
An overview of the emergence of Takaful: An Islamic type of insurance policy
}

\author{
Suria Zainuddin*, Izyan Nadiah Md Noh \\ Faculty of Business and Accountancy, University of Malaya, Kuala Lumpur, Malaysia \\ Email address: \\ suriaz@um.edu.my(S. Zainuddin),izyannadiah@gmail.com(I. N. M. Noh)
}

\section{To cite this article:}

Suria Zainuddin, Izyan Nadiah Md Noh. An Overview of the Emergence of Takaful: An Islamic Type of Insurance Policy. International Journal of Business and Economics Research. Vol. 2, No. 5, 2013, pp. 112-115. doi: 10.11648/j.ijber.20130205.13

\begin{abstract}
The Islamic type of insurance policy, called Takaful, is increasingly known at present and attracts the attention of the insurance holder especially in Islamic country like Malaysia. The purpose of this article is to provide basic definition and offer some explanations of takaful and how it differs from conventional insurance. It is also aimed to increase the understanding of takaful and avoid misinterpretation of the concept and applications of takaful, an Islamic type of insurance policy.
\end{abstract}

Keywords: Takaful, Islamic Policy, Islamic Insurance, Conventional Insurance

\section{Introduction}

Takaful industry existed in 1984 is considered a new reality in the international financial scene. Its philosophies and principles are however, not new, having been outlined in the Holy Quran and the Sunnah of Prophet Muhammad (SAW) more than 1400 years ago. The emergence of takaful is often related to the revival of Islam and the desire of Muslim to live their lives in accordance with the teachings of Islam.

Following to the decree issued by the Malaysian National Fatwa Committee who declared that the conventional life insurance contradicted with the Islamic principles and considered haraam (void), takaful's growth in Malaysia was triggered by then. Subsequently, the Fiqh Academy of the Organization of the Islamic Conference (OIC) has also decided that all forms of conventional insurance do not adhere to the Islamic tenets. In Malaysia, a task force was then set up in 1982 and based on its recommendations; the Takaful Act 1984 was then enacted. Since the enactment of the Takaful Act 1984 which provides establishment and regulation of takaful business, Malaysia is the forefront in the global takaful industry.

\section{What is Takaful?}

Section 2 of the Malaysia's Takaful Act 1984, defines takaful as "a scheme based on brotherhood, solidarity, and mutual assistance which provides for mutual financial aid and assistance to the participants in case of need whereby the participants mutually agree to contribute for that purpose" [1].

The essence of takaful is based on the system of mutual help in relation to the custom of blood money under the Ancient Arab tribal custom, and eventually was approved by the Prophet (pbuh). The aqila system as practiced by the Muslims of Mecca and Medina was on the basis of shared responsibility which laid the foundation of mutual insurance. The Prophet's companions later followed this practice too. Aqila aimed at helping those in need without demanding contractual payments as well as non-commercial in nature. It is instead relied very much on the sense of brotherhood and mutual responsibility to contribute to fellow members of the tribe who are in need. For instance, the accused person's paternal relatives will bear the responsibility of paying the blood money which is pooled from the group member's contributions to the victim's relatives in the case of unintentional murder involving two different tribes [2].

In the current situation, the spirit of insurance is often portrayed in social work such as cooperation in helping friends and neighbors in a big feast, repairing defective houses and lifts the belongings of those who are moving out. This mutual cooperation and responsibility and the provision of financial benefits are indeed encouraged by Islam. Therefore, a system of mutual help being the basis of insurance and Takaful is not contradictory to the Shariah.

Shariah basis of takaful can be found in the holy Quran in Surat al-Maidah verse 2; 
"Help ye one another in righteousness and piety, but help ye not one another in sin and rancor, fear Allah, for Allah is strict in punishment" $(5: 2)$ [3].

In Malaysia, a fatwa was issued by the National Religious in 1982 pronouncing that conventional life insurance is not permissible because of the elements of gharar (risk), maysir (gambling) and riba (interest). Family Takaful was then developed in 1983 in order to provide an alternative to conventional insurance. Takaful Act 1984 was passed in order to further uphold the legality of Takaful in Malaysia. The said act marks the history after being the first written law in the world to regulate Takaful business in which it empowers the Shariah Advisory Council to supervise, monitor and advise on Takaful operations at the national level while the Shariah advisory committee at the institutional level.

It was decided by Muslim jurists that principles of mutuality and co-operation should be the basis for insurance in Islam. The elements of shared responsibility, joint indemnity, common interest, solidarity and so on are embodied in the Takaful system due to the basis of these principles. This concept of insurance is acceptable in Islam due to:

- Cooperation among participants for their common good.

- Payment of contribution by each participant in assisting any fellow members in need.

- His contribution is considered a donation (tabarru') to the members in the group.

- Losses are divided and liabilities are spread equally according to the community pooling system from the contribution.

- Uncertainty was eliminated as the terms in the contribution and compensation are made clear to the participants.

- Deriving advantage at the cost of other individuals is not the aim of the system.

Therefore the concept of insurance itself is not against the spirit of Shariah. In fact, mitigation of risk by adopting the law of large numbers was widely used, particularly in the practice of aqila as mentioned earlier.

The intensification of takaful business in Malaysia has been tremendously remarkable, more Muslims and even non-Muslims are aware about the mechanism of the system as well as positive support from the government. Products of takaful are ranging from general to family takaful, and include the specialized ones like marine and health. The contributions are invested in Shariah compliance shares, bonds and money market instruments.

General takaful contract is normally a short-term policy where takaful participants pay some contributions and operators undertake to manage the risk. The contributions paid by the participants are credited into the general takaful fund, which is then invested and the profits generated are paid back to the fund.

The tabarru' element is more apparent in general takaful as participants will normally undertake to regard their contributions as donations to fellow participants. All contributions go to a common pool of funds which will be used to compensate takaful participants in the event of a loss. There are no savings and investment elements, but the takaful operator will distribute any underwriting surplus to the participants on annual basis. Typically, general takaful is short-term but renewable periodically, in both retail and corporate segments. General takaful is categorized in two types; motor takaful and non-motor takaful. Motor takaful provides protection for private car, motorcycle and commercial vehicle. Non-motor takaful ranges from fire to personal accident and include marine, health takaful and many others.

Family takaful on the other hand is a long-term policy for which most participants aim at saving for their long term needs. Among the most common and typical family takaful products offered include savings and educational plans, retirement plans, retirement annuities, waqf plans and ancillary benefits added to the main plans, such as protection for critical illness, disability, accidental death, or waiver contribution. This type of takaful has a long-term time horizon which ranges from ten to thirty years. In family takaful, operators normally divide the contributions into two parts: first, the participant's account (savings account) and second, the participant's special account (tabarru' account) for meeting losses of fellow participants. In the event of a loss, the participant will be compensated according to a pre-agreed formula. If a participant dies prematurely, his family gets the amount in the participant's account plus dividends, and amount in the participant's special account as if he continued contributions until the maturity period. If the participant withdraws from the takaful program, he will get the amount in the participant's account only. Accordingly, the clause of tabarru' is incorporated in the contract. Both accounts are invested in Shariah-approved securities. Depending on the type of underlying contract, the takaful operator may receive a fee or share of investment profit.

\section{Types of Contract in Takaful}

Shariah provides various types of contracts to suit the needs of contracting parties. Each contract has unique features and rules which are in line with the objective of the respective contract:

\subsection{Contract among Takaful Participants - Tabarru'}

Tabarru' is an agreement by a participant to relinquish, as a donation, a sum of contribution that he or she agrees to pay into a takaful fund. Participants give certain portions of their contribution as a donation with the purpose of providing mutual indemnity to takaful participants, where the donation acts as a mutual help joint guarantee should any fellow participants to suffer from a defined loss. The current practice does not specify the exact donations, whether it is an outright gift (hibah) or endowment (waqf). According to the Accounting and Auditing Organization for Islamic Financial Institutions (AAOIFI) the practice is known as 
iltizam bit tabarru' or nihd.

\subsection{Contracts between Participants and Takaful Operator}

There is no insurer-insured relationship between participants and the takaful operator because the participants are insuring themselves. The takaful operator is engaged by participants (in a group) to manage the takaful scheme for them. The parties can adopt any of the following contracts depending on their needs; namely, mudarabah, wakalah, ju'ala, waqf, or a combination of the earlier contracts (hybrid).

Mudarabah means the giving of capital to another person who will trade with it for the purpose of sharing the profits according to a pre-agreed ratio. Investment is a side activity to optimize the fund. In takaful, the capital providers (rabbul mal) are the participants and the investment manager (mudarib) is the takaful operator. The investment manager (operator) must invest in a Shariah-compliant manner and in accordance to the terms in the takaful contract. Profit, if any will be shared based on a pre-agreed ratio. If there is a loss, it will be borne by the capital provider. However, if the loss is due to the manager's negligence, then the manager must be jointly responsible for the loss.

Wakalah is a contract of agency, whereby participants remain the actual owners of the takaful fund. In this arrangement, the principal is the participant while the agent (wakil) is the takaful operator. The principal appoints or authorizes the agent to manage the takaful fund for two main duties, namely, takaful activities (underwriting, paying claims, etc) and investments. As an agent, the operator is entitled to an agency fee (agent's remuneration) and performance fee (agent's commission).

Ju'alah refers to a commitment to pay a specified amount of reward for the performance of a prescribed task. On the basis of this contract, the participants collectively appoint the operator to manage the takaful fund, in a prescribed manner, for a specified reward if done accordingly. Payment is based on actual output and performance.

Waqf means a unilateral contract to relinquish a right over property and allocate it for general enjoyment of the usufruct by the specified beneficiaries. It can be made applicable in the treatment of a takaful fund, while management and operational aspects of the takaful fund may still use wakalah and mudarabah contracts. Participants will give contributions into a waqf fund, and thus completely lose the right over their contributions. The takaful operator acts as a trustee to the waqf fund.

While the hybrid of wakalah and mudarabah models combines some features in both models. The wakalah principle is applied in underwriting activities while a mudarabah contract is used in the investment of the takaful funds. Thus, the takaful operator is entitled to agency fee for managing the fund as a wakil and share a profit for managing the investment of the fund as a mudarib.

The hybrid of wakalah and waqf model has emerged from Pakistan and was introduced by Taqi Usmani. The general concept behind this model is that it is designed to enable any individual to save regularly with aim of accumulating a fund that can be left as a donation under the waqf system. In this model, the shareholders of the takaful operator will initially make a donation to establish the waqf fund. The fund needs to be invested in a Shariah-compliant investment, and the returns will be used for the benefit of the participants. The tabarru' fund from participants' special account also becomes part of the waqf fund.

\section{Takaful vs. Conventional Insurance}

The fundamental difference between takaful and conventional insurance is rooted in the type of contract. The conventional insurance contract is basically constructed between two parties, namely the insured and an insurance company. The insure deals with the insurance company by paying regular installments (premium) in return for the guarantee to pay compensation, in case the event stipulated in the contract happens. It is thus one of the probabilistic contracts since the compensation is contingent on events that may or may not occur. This definition and nature of conventional insurance invoke many Shariah issues.

Takaful differs from conventional in the sense that the takaful operator is not the insurer insuring the participants. In fact the persons participating in the scheme, or takaful participants, mutually insure one another. This is the essence of takaful that signifies mutual guarantee, help and cooperation with one another. The takaful operator simply functions as administrator of the takaful fund and whose responsibility includes managing and investing the fund according to Shariah principles. The Takaful Industry Report recognizes that the sharing of responsibility between the shareholders and policyholders is the exclusive difference between takaful and conventional insurance [4].

Earlier, in 1965, the Congress of Islamic Research in Cairo also has discussed the legitimacy of insurance in the Islamic world. In the First International Conference on Islamic Economics held at Mecca, Saudi Arabia in 1976, international consensus was reached that insurance for profit is contrary to the Shariah. This was confirmed by the Islamic Fiqh Academy at Jeddah in 1985. "The contract of commercial insurance with periodical fixed premium provided by the present day insurance companies is a contract which is void and therefore haraam in accordance with the requirement of Shariah."

The European Council for Fatwa and Research has reaffirmed the rulings: "Commercial insurance is originally haraam as agreed upon by most contemporary scholars. It is well-known that in most non-Islamic countries there are co-operative and mutual insurance companies. There is no harm from the Shariah point of view to participate in these activities."

\section{Conclusion}

In sum, conventional insurance is strictly prohibited in Islam as it violates Islamic principles. A fatwa was issued by 
the Malaysian National Fatwa Committee in 1982 announcing that conventional life insurance is not permissible because of the elements of gharar (risk), maysir (gambling) and riba (interest). Muslims are prohibited to purchase conventional insurance as it is haraam and violates Islamic principles. As nowadays there are alternatives to the conventional insurance, Muslims should choose takaful, the Islamic types of insurance policy, which is approved by Shariah.

\section{References}

[1] Takaful Act 1984 (2007). Kuala Lumpur: International Law Book Series.

[2] Islamic Financial System: Principles and Operations. (2011). Kuala Lumpur: International Shari'ah Research Academy for Islamic Finance (ISRA).

[3] Al-Quran, (5:2).

[4] Echachabi, L.O. Ayinde, and Abdelghani, "Perception and adoption of Islamic insurance in Malaysia: An empirical study," World Applied Sciences Journal, vol. 20, issue 3, pp. 407-415, 2012. doi: 10.5829/idosi.wasj.2012.20.03.1954. 